\title{
Cultural Symbols and Landowners' Power: The Practice of Managing Scotland's Natural Resource
}

\author{
Andy M. M. Samuel \\ School of Social and Health Sciences \\ University of Abertay Dundee
}

\begin{abstract}
This article deals with the claim that Scottish landowners' power is directly related to their status in law, by arguing that it is, in fact, much more to do with their (inter)relationship with particular cultural symbols that can be associated with the land. However, this presents a sociological problem, for the dominant sociological purchase on land is one which routinely interprets it as a social construction. The paper presented here differs, as it focuses on particular cultural symbols which have a socio-historical resonance in relation to land, and makes the argument that they maintain this presence because of their (inter)connection with particular social groupings, notably landowners. Therefore, it is simply not enough to identify landowners' status in law as the root cause of their power, but instead it should be seen as only one facet of it. I conclude by suggesting that just as important is the way in which landowners have appropriated cultural interpretations of the land to forefront their powers.
\end{abstract}

KEYWORDS culture, heritage, land, landownership, Scotland, symbols

As the Scottish Parliament establishes itself, Scottish landownership is being recognised as one of the most 'pressing' and 'talismanic' issues on the agenda (Callander 1998). At its heart is the need to tackle the controversial system of land tenure in the country. Half of Scotland's land is owned by a mere 500 people (Wightman 1996:142), many of whom are said to be exploiting the country's socalled 'feudal' land system (Cairns 1996) to the full.

Scottish landowners' power is manifest in the many recent cases of their detrimental treatment of house and business tenants as seen on, for example, the Island of Eigg. Here, the island's former owner on buying the island in May 1995 promised to develop its infrastructure. The promise was more than welcomed by islanders as previous landowners had failed to invest in the island at all. Yet despite this undertaking, the financial resources needed for such infrastructural development were not forthcoming. Indeed, the new owner went as far as to renege on paying wages to his estate workers (the dominant type of employment on the island) for at least two months (for a detailed account of the ownership of Eigg, see Dressler 1998). Unfortunately, this form of treatment is a common occurrence (see Outterside 1996; Cairns 1996), and has fed into a growing debate about the 'land problem.' ${ }^{1}$ 
The general assumption underpinning the explanation of this problem is one which sees it as rooted in the character of Scotland's 'ancient land law'. Here, as the argument goes, the law dictates that every owner or tenant of a house which falls within the boundaries of a 'landed estate' has a 'feudal superior'. The superior is entitled to make demands upon the house owner or tenant, including charging a 'minute of waiver' 2 should either wish to develop or build an extension, or exercising a right of pre-emption to buy the owner's home. Hence, the 'land problem' is commonly interpreted as being rooted in this legal situation which gives too much power to landowners at the expense of house owners or tenants (see Cramb 1997; Wightman 1996; Outterside 1996; Cairns 1996, Hunter 1995).

My contention is that the above assumption is based on a misunderstanding of landowners' power. Simply put, it fails to appreciate the position of the landowner in Scottish social and cultural history. This, I propose, is just as important as their status in the law (Samuel 1996, 1998; see also McCrone 1997); indeed, landowners' very position in law may itself be a reflection of their socio-historical relationship with the House of Lords. Therefore, it is simply not enough to identify a 'feudalistic law' as the root cause of their power, but instead it should be seen as only one facet of it. As I hope to empirically substantiate, just as important is the way in which landowners have appropriated cultural interpretations of the land to forefront their powers.

Williams (1973) and McCrone $(1997,1992)$ to name but two,have - correctly, in my opinion - argued that Scottish peoples' views of land are related to their ideas of 'nationhood'. ${ }^{3}$ Consequently, notions about the land are associated with a powerful set of political, social and cultural expectations and values. Such notions are easy to caricature: 'wild', 'mountainous', 'unspoilt', etc. They are, in sociological terms, 'symbols' ${ }^{4}$ of Scottishness. The question I want to address here is 'how' and 'why' these interpretations of the land maintain their social purchase (see Barnes 1981 for a discussion on the differences between the 'how' and 'why' questions in sociology). The following is an attempt to uncover the cultural complexities of the 'land problem' so as to help answer this innately sociological question. I start by contextualising (I use this term in the same way as Knorr-Cetina 1979) the land question, looking at orthodox histories of landownership in Scotland. This is followed by a critical appraisal of the potent argument on landowners' power provided by Cannadine (1990). He postulates that landowners have lost their power in modern British society, while the suggestion here is that this argument is based on a generalised notion of power which has it that it is rooted in economic wealth. Rather, my discussion is oriented towards the idea that power is much more than economic, it is also social and cultural; a situation I argue herein that is readily apparent in relation to Scottish landowners' power. The paper goes on, however, to take issue, if modestly, with the way in which sociology has articulated the sociocultural dimension of Scottish landowners' power. Specifically, I critically engage with McCrone et al.'s (1995) assertion that the concept of 'status' can 
unproblematically be used to account for their culturally privileged position. Instead, I call for a more 'relational' account of power. This paper, using Bourdieu's theoretical programme, concludes by empirically suggesting that Scottish landowners' power is today based on their interrelationship with Scotland's natural environment.

\section{The Historical Roots of Landowners' Power}

The historians Roger Millman (1971), John McEwen (1977), Loretta Timperley (1980) and Robin Callander (1987) are in agreement that landowners have been unusually powerful in Scotland. In Timperley's words: 'Power and landownership have been synonymous in Scotland from time immemorial' (1980:137). She went on to document landownership patterns in 1771 establishing that 'the overall control of Scotland's land by the great landlords' - defined by her as those landlords who owned more than $\mathfrak{k}_{2,000}$ Scots - 'was most complete in the Borders at around 65 per cent, and up the east coast, at between 40 per cent and 50 per cent' (Timperley 1980:48). The West Coast and Central regions were different, however, with landlords never owning more than 35 per cent of the land. Timperley shows how most of the larger estates were owned by titled families who constituted eighty-one out of the 123 wealthiest families.

Callander points out: 'The 1,500 largest landowners ... had held over 90 per cent of the country in 1872 , and this had only dropped a percentage point or two thirty years later' (1987:78-9). However, over the course of the twentieth century there has been a reduction in larger estates, an increase in the number of small owners, and a growth in the land owned by non-governmental organisations (NGOs), the state and public agencies like the Forestry Commission. Yet even though there was some visible reduction in the number of very large estates (over 20,000 acres), 'the traditional estate survived with a fair degree of constancy during the period 1872 to 1970' (Callander 1987:81), despite some frequent changes in ownership. This higher turnover was, in Callander's view, because the estates were simply too few in number and mostly owned by absentee landowners; but he concludes that, 'the present pattern of landownership in Scotland still matches closely the earlier pattern stretching back through the last nine centuries' (p. 131). In substantiating his claims, he quotes Sir John Sinclair: 'in no country in Europe are the rights of proprietors so well defined and so carefully protected' (p.136).

These historians have shown how landowners were tremendously powerful agents in Scotland, but some have taken the argument further (Cannadine 1990) and claimed that today's landowners are relatively powerless compared to their predecessors. It is an argument that warrants attention if simply to dispel its potency, but in critically tackling it I also hope to clarify my own position. Below, then, I set out the main tenets of Cannadine's proposition. 


\title{
A Decline of the Landed Elite
}

David Cannadine in his important work, The Decline and Fall of the British Aristocracy (1990), proposes that there has been a relative decline in the power of the landed elite. For example, he argues (p. 2):

\begin{abstract}
These patricians were still the wealthiest, the most powerful and the most glamorous people in the country, corporately - and understandably - conscious of themselves as God's elect. But during the 100 years that followed [the 188os], their wealth withered, their power faded, their glamour tarnished, and their collective sense of identity and purpose gradually but inexorably weakened.
\end{abstract}

He puts this decline down to the long fall in land prices after the 1880 os with the result that landowners lost 'prestige' and 'status'. For example, between 1912 and 1920, the land agents Knight, Frank and Rutley sold a reputed 1.6 million Scottish acres one-twelfth of the land area of the country (Cannadine 1990:109). Considering Britain as whole, during the period immediately before and after World War I, one-quarter of the land in England was sold, as well as one-third of Wales and onethird of Scotland (quoted in McCrone et al. 1995:121). It was also a period, Cannadine points out, in which many estate owners were obliged to sell many of their art treasures (Cannadine 1990:112). In all, it was a time when landowners' power passed to a new class of rich 'plutocrats' (p. 113). Indeed, he argues that by the 1980s, 'the old landed orders had effectively ceased to be an economically definable class at all' (p. 638).

Thus, in Cannadine's view, the last 100 years were witness to the decline of the landed aristocracy as a social class: 'The fact remains that the traditional landed class has ceased to exist as the unchallenged and supreme elite in which wealth, status and power are highly correlated, and are underpinned by territorial pre-eminence' (Cannadine 1990:693). Cannadine argued that their decline was witnessed in the amount of estates being sold (Sutherland's, for example, shrank from 1.3 million acres in 1880 to a mere 138,000 in 1976) and in how the imposition of new taxes stretched landowners' financial base. Even the establishment of a National Heritage Memorial Fund in 1980 was, as he comments, a sign of weakness in so far as it recognised estates and their associated 'country houses' as relics of a once 'golden past'. The fund and its agents, particularly the National Trust and the National Trust for Scotland, were 'undertakers, embalming these once great power houses for posterity' (Cannadine 1990:655). In his words, 'The lions of yesteryear have become the unicorns of today' (p. 708).

However, sociologists have argued that Cannadine's thesis is based upon a particular theoretical rendering of landowners' power and their downfall; one that equates power with economic wealth. For example, in their book, Scotland the Brand: The Making of Scottish Heritage (1995), McCrone et al. ${ }^{5}$ contend that Cannadine: 'sees [landowners'] economic base as a class challenged in such a way that they were 
progressively unable to translate wealth into social prestige and political power. And almost automatically their social position declined' (McCrone et al. 1995:121). However, McCrone et al. contend (and I agree) that Cannadine is wrong to argue that a decline in landowners' power was marked by their economic demise. Their argument pivots on the consequential nature of such an economic demise.

They criticise Cannadine for suggesting that landowners' increasing economic marginality confined them to the 'cultural fringes', notably as custodians of Scotland's 'heritage' where they operated 'as the self-styled and self-promoting guardians of what they like to call the national heritage' (Cannadine 1990:639). Thus, according to Cannadine, the role of keepers of Scotland's historical past was a new role which landowners 'invented for themselves', which was little more than a bad attempt to preserve some of their authority and public respectability.

Following the logic of Cannadine's thesis - that the landed elite have lost their power - McCrone et al. argue, one would expect that landowners should have disappeared altogether, yet 'landed hegemony', within Scotland at least still prevails (1995:127). Contrary to Cannadine, they point to landowners' contemporary position as guardians of the heritage industry, as legitimating their authority. As McCrone et al. argue (1995:127):

the move into the [built] heritage industry by [eminent landowners] is not just an attempt to fill up their time following the end of Empire. One key to understanding why they became eminent Scottish heritage entrepreneurs lies in their exit from [public life]. Stripped of their [public] function, the [built heritage] industry represented a way of securing their economic future as well as a means of legitimising their privileged position.

However, unlike McCrone et al., ${ }^{6}$ my argument ${ }^{7}$ is that to fully understand the authority of landowners, their appropriation of a cultural interpretation of the land in Scotland ought also to be considered. To this extent, I see landowners' claims that they are custodians of the land as being an attempt to (re)gain legitimacy in Scottish society - one that has, in fact, succeeded in positioning them as authoritative within it.

In substantiating my claim I turn to Bourdieu's theoretical programme. In using his terms, the argument is that as landowners' economic resources have waned, they have changed their acquisition tactics, albeit implicitly, to those based on the accumulation of 'cultural capital' ${ }^{8}$ In this way, they were able to regain their powerful position. As Thompson (the editor) argues in the introduction to the English copy of Bourdieu's Language and Symbolic Power (1991), in countries like Britain where the dominant position of institutions in everyday life is manifest, and where interpersonal' strategies that are used to claim and legitimate authority have waned (like economic accumulation), these strategies simply change into something different. As he states: 'The development of institutions ... enables different kinds of capital to be accumulated and differently appropriated, while dispensing with the need for individuals to pursue strategies aimed directly at the domination of others.' 
(Bourdieu 1991:24). Hence, Thompson argues that any attempt to explicate the strategies agents use in a social space (a field, to use the terminology) must start with an analysis of the way in which 'institutionalised mechanisms' tend to deal with 'allocation' and 'fix the value' of products common to the field. The heritage industry provides a good example of this process: I argue below, that the development of this industry involves a certain kind of 'objectification' (using Bourdieu's sense of the word - see Wacquant 1989:33) of the land. One in which 'Scotland's history' becomes a mechanism for creating and sustaining inequalities, in such a way that the use of economic resources (by landowners) becomes less prominent. Moreover, by concealing the link between the way Scottish history is interpreted by a landowner and the cultural capital relating to this history that they inherit by virtue of their social background, the heritage industry provides a practical justification of the established order. As Thompson succinctly puts it, the heritage industry, 'enables those who benefit most from the system to convince themselves of their own intrinsic worthiness, while preventing those who benefit least from grasping the basis of their own deprivation' (cited in Bourdieu, 1991:25). Thus, Scottish landowners' ability to maintain power in Scottish society is not simply based on their control of land through their position in law. Landowners' maintenance of power is also due, as I argue below, to their cultural significance as 'custodians of the land'.

\section{A Power Transference, Not a Demise}

My argument starts on a similar basis to that of McCrone et al. - that the term 'laird' is an ambiguous one and in consequence affords any one in possession of land in Scotland a degree of symbolic significance. For example, McCrone et al. state (1995:127):

from the old Scots word 'Laverd' - a lord - but refers, according to the Scots Dictionary, to: (a) a prince or chief; (b) the landlord of a landed property or an estate; (c) the chief of a Highland clan; (d) 'chiefly of lesser landowners, a landowner holding directly to the Crown, and so entitled to come to Parliament (until the eighteenth century), but not a lord of Parliament'; (e) an owner of property in general, including a house owner.

They go onto argue that 'this ambiguity served as an important resource for landowners in a country which has frequently been less than hospitable towards them' (p. 128). It operates as a device that legitimates their authority by connecting them with the 'status' of a Scottish Lord. The concept 'laird', they continue, 'is something of an umbrella term which binds the small landowner to the mighty Lord for ideological purposes' (p. 128). It is an assertion based in the belief that landowners, 'in general can be seen as a status group' (p. 126, my emphasis) - the point at which I disagree with them. McCrone et al. (1995:123) adopt Weber's concept of status group, ${ }^{9}$ because it lends them the possibility of being: 
able to define how the landed elite tried to define and control the boundaries of the group, to allow entry to those with new sources of power, and to exclude others. Above all, such a perspective allows us to focus on aspects of lifestyle, on the social rather than on the economic means of control and boundary maintenance. In this way we can see aspects of social consumption, beliefs and lifestyle not as the inevitable outcomes of economic processes, but as relatively autonomous from class position.

In this sense, property as an economic (or legal) entity can also be seen to help characterise a 'status' which is analytically independent of class.

However, there is a problem with this definition of status, which is to do with practice. Status is used by McCrone et al. to explain how lairds are still (despite their waning 'economic class power') a powerful grouping in Scotland. Lairds' status, they argue, is a characteristic of a particular 'lifestyle' (McCrone et al. 1995:124), whilst in the course of time the particular cultural traits which this lifestyle embodies become internalised ( or as Weber would term it 'habitualised'). Their analytical stance is one where they try to identify the explicit formulations of supposed lifestyles before they are internalised - that is, they analyse them when they are 'visible'. For example, a number of historical accounts of 'lairds' (for instance, Fergusson 1949; Johnston 1911) are examined, which explicitly attach particular cultural traits to landowners' lifestyle. In doing so, McCrone et al. (1995:120) are able to imply that Scottish landowners were able to assert their authority by differentiating themselves religiously and politically from the rest of Scotland. These traits become an implicit condition of the laird's way of life. This leads to the suggestion by McCrone et al. that: the concept of 'laird' provides a 'ideological device in the legitimation of power' (1995:128). Thus, landowners are able to use the status the concept of laird bestows on them, including, to quote McCrone et al. (1995:128), the ownership of 'property'.

However, in my opinion there is a problem with this idea of status, which is to do with reproduction (or extended practice); an explicit lifestyle, the argument goes, originally produced by individuals wishing to define themselves as different, in time becomes implicit - a set of dispositions or that which is habitualised. ${ }^{10}$ Indeed, McCrone et al. seem to analytically engage with a particular cohort of landowners based sometime around the end of the nineteenth century, while work on modern landowners' lifestyles is relatively minimal. Here, the question is raised: if the power of Scottish landowners is embodied in their take-up of implicit traits (or dispositions which make up their status), which belonged to an older generation, in what way were they passed on? The question is pertinent if we are to believe McCrone et al'.s argument that landowners in Scotland still enjoy a similar status to that of their immediate forbears. As Turner ${ }^{11}$ has remarked, the question of the temporal stability of a status lifestyle, 'brings us to a fundamental problem'. 'The mechanisms of habitualisation ... are not a very good model for the processes of [reproduction] that are required by the concept of practice' (1994:61). In the next 
section, I offer a suggestion as to the way in which this problem can be overcome, at the same time setting out my academic purchase on the concept of 'reproduction'.

\section{Landowners' Power and Land Management Practices}

In using status as McCrone et al. do, one is faced with what can be termed the problem of reproduction; ${ }^{12}$ in short, what social mechanism assures that implicit traits which demarcate a status are shared? The idea that a practice is reproduced requires some means of 'reproduction' which assures the practices are similarly enacted over time and space; making external behaviour 'the same' through a discipline or training is something we understand, but education and discipline both act directly only on performance (on external behaviour). Making internally held values (which make up a lifestyle) 'the same' is a different matter. ${ }^{13}$

Bourdieu in Distinction: A Social Critique of the Judgement of Taste (1984) rethinks Weber's differentiation of class and status group by considering how cultural capital mediates the complexities of class-based status. In using his theory, individuals and their trajectories are not described by their possession of particular characteristics (for example, lifestyles), but by their relationship to symbolic resources which describe the field in which those individuals occupy a position. It is in understanding the complex structure of the field, described by the possession of symbolic resources - deep-rooted cultural phenomena associated with the land, for example - which are descriptively and analytically related to a particular habitus, ${ }^{14}$ that the analytical and empirical payoff to employing notions of symbolic capital instead of the more standard and independent or non-relational notion of status lies.

Thus, the use of particular symbolic capital can be related to a particular habitus, which structures the rest of the field. Here, landowners' use of cultural capital binds them to the land in a way which, on the one hand, associates them with Scotland's natural heritage but, on the other, makes the land their property, and thus allows them a powerful position in the country. In this sense, the relationship conveys a very modern idea of legitimacy - that the laird is the custodian of Scotland's natural heritage and consequently the country itself. But, and this is central to my argument, in order to assert themselves as guardians of the land, or legitimately appropriate the land, landowners have had to rely on historically resonant interpretations of this land. In the following, I consider the above claim in detail. My discussion is aimed at empirically setting out the mechanism of reproduction.

\section{The Land and Lairds: The Case of Red Deer}

The claim that landowners use a particular type of symbolic capital based on their near monopolisation of the land, can most readily be appreciated when the story of landowners' relationship to the red deer is analysed. Here, there is a close 
correlation between the pattern of landownership that dominates in Scotland and the right to hunt red deer (see Gill, 1990). It is a relationship that has its origins in the development of Scotland's feudal land-tenure system and the 'symbolism' and pleasure (sic) which has long been associated with hunting. As Darling, a famous Scottish nature conservationist, poignantly wrote, (1937:27):

[deer] are animals whose lot has been closely linked with human development. We have pitted our wits against them through thousands of years and the hunter is not worth his [sic] salt who does not admire this quarry and is not content sometimes to watch the beauty of their lives, free from the desire to kill.

However, though the history of the red deer may be related to the history of humans, little is known ${ }^{15}$ about the relationship. Anthropological or archaeological evidence is sparse, but in a study of the Isle of Rum (Love 1980) some substance is given to the claim that deer played a central part in the Scottish culture (or at least West Coast culture) of the middle ages. ${ }^{16}$ This evidence is based on the existence of 'deer traps' large funnelling stone dykes starting near the top of a mountain ridge a few hundred meters apart and leading down its side to meet and create a small entrance to a large circular enclosure whose walls have been measured as over two metres high.

These deer traps are important for the argument here, because they clearly establish that deer have been an intricate part of Scottish culture for much longer than most people would believe (for example, see Scottish Natural Heritage 1994). Commonly, the importance of red deer has been tied to the rise of the Sporting Estate (Hart-Davis 1978), where it is traditionally suggested that the rise of this land management regime is associated with the strengthening of the legal control of hunting, specifically stalking (Callander and MacKenzie 1991). Conversely, the control of deer stalking itself (and other hunting practices) can be seen as a major influence on landownership patterns in the Highlands. It is a situation that has demanded that nature be separated and valued in accordance with the distinction between those animals which are worth hunting and those that are not. Over time, it can be seen as a practice, which has become embedded in the very character of landtenure laws in Scotland.

The implication is that the development of large estates was dependent on the rise in popularity of deer stalking. However, this is to miss the point; large estates, I would argue, are not a consequence of the success of deer stalking, because this stalking is itself dependent on the land tenure system (as manifest in the large estate). Here, landowners have successfully managed to maintain their authority over land in Scotland by positioning their rights as based in a particular cultural appropriation of red deer as quarry. But in so doing, and this is the crux of my argument, these landowners are implicitly connecting their control of the land with historically resonant practices based on red deer as a symbolic resource - i.e. quarry.

Here, the modern day 'stalk', if my argument is believed, a concept that is firmly 
rooted in Scottish history, is controlled by landowners. Thus, they are here legitimising their position not simply through recall to the law, but in relating themselves to historically resonant practices which have patterned the cultural meaning of Scotland's land - its contextuality (Knorr-Cetina 1981). Below, I expand and clarify this point.

\section{Lairds as Improvers of the Land}

As I have discussed above, the conventional academic wisdom that surrounds the issue of landowners' authority in Scotland is that it is or was based on their financial wealth (Cannadine 1990), which some have argued gave way to their legal status in law (McCrone et al.1995). There is clearly truth in this, but it is not the whole story for landowners' authority, as I argue, also relies on their monopolisation of historically important interpretations of the land and phenomena thereof. In other words, they are basing their claim to authority in the Scottish field on the 'acquisition of a reputation for competence and an image of respectability and honourability that are easily converted into political positions as a local or national notable' (Bourdieu 1988:291) - a notable such as a laird. This is done in a way that, first, sits harmoniously with a traditional land management system that depends on being sensitive to historical practices - treating red deer as quarry - and, secondly, takes into consideration the interests of the local community who have a stake in these practices. Indeed, as Lord Pearson of Rannoch (1991:173) has remarked:

Deer management is a wider industry than the sporting interest in deer, which is important. Deer management includes the whole welfare of our largest animal, one that must be judged by any standards to be among the most beautiful. Deer management depends on the ownership or tenancy of the land in a way that many other land-uses do not.

The purpose of this claim is clear - to legitimate landownership by attaching it to the management of our largest and most beautiful animal. Its welfare depends on this very landownership system. Here the justification that gives landowners power, is not simply to do with their status in law, but is equally to do with their ability to attach their management of the land with a set of pre-existing relationships among local people and the land. As Bourdieu argues (p. 291), when an agent bases their accumulation strategy on the acquisition of cultural capital: 'it is therefore understandable that [landowners in this case] should identify with the established (moral) order to which they make daily contributions, of which their political positions and actions ... are only the most visible form.'

This contextualisation of the field is borne out in the way landowners can be seen to create a fusion between their interests and the practice of conserving the land. It is an amalgamation of concerns which is nicely captured in the following comments by 
authors who supported the estate ownership system: 'our heritage is best preserved by those who own [the land] because they know it and love it' (Charteris 1991:141), 'landholders are vital to the countryside. 'They made it and they look after it' (Grimond 1991:147). The point here is that there is no distinction made between landowning and caring for the environment, but instead the two are interwoven in a way that justifies the position of landowners as custodians of the land.

As McCrone et al. state, 'estate guidebooks provide the ideal format for this interweaving' with their onus on connecting the traditional management of the land with generations of the family, referring to the planting of today's 'great forests', or farming practices 'dating back centuries'. Here, the story of Scotland's natural history is told through the medium of estate ownership linked with the genealogy of one specific family. Thus, the family and the land became united. For example, Rothiemurchus estate guidebook (see Grant 1991:21) explains:

The main activity on Rothiemurchus is farming. The low-lying flat land by the Spey and the surrounding moorland and woodland make ideal areas for rearing high quality beef cattle and wintering sheep. The production of weaned calves from the hills has been carried out in this area for centuries. Some old drove roads, which connected the hill rearing areas with Southern fattening areas, can still be traced and many are now available as footpaths.

Here, farming is represented as the most important activity on the estate and is identified as a historical one, carried out for centuries on specific pieces of land. In the same guidebook, the family of the present landowner is also firmly connected with the area, having owned it since the fourteenth century (Grant 1993:1). Yet at the same time, the landowner is, in the words of the Buccleuch guidebook, only 'a life trustee dedicated to the constant improvement of a vital asset to the benefit of everyone concerned, as well as future generations of [the Buccleuch family], on whom the responsibility for future progress rests' (cited by McCrone et al. 1995:132). The guidebook, then, is not simply a guide to the layout of an estate, but a chronological narrative of how the dynasty has come to occupy the position it holds. The Buccleuch guidebook, cited by McCrone et al. (1995:133), continues:

Once the links in the chain are broken, through the irreversible process of the break-up of estates, the merits of multiple land-use are lost forever. The advantages of continuity spanning many generations apply just as much to the families of those who occupy let farms and estate employees. On Buccleuch estates some family partnerships between landlord and tenant go back possibly as far as the 12th century.

Thus, landownership and land are intricately connected and interwoven with a theory of history in an anecdotal and informal sense, and with a theory of landtenure. The great Scottish landowners see themselves as champions of Scotland's natural assets, creating and maintaining them in a way that is compatible with the interests of all. 


\section{Conclusion}

I have argued here that because of the decline of their economic credit, landowners have recently had to (re)-struggle for authority in the Scottish field. In so doing, they have used a certain form of cultural capital, drawing on established historically resonant practices which link them with the land and Scotland in general, but specifically with local residents. First of all they have argued that their management techniques have historical justification because of their connections with the Scottish people, stalking being a historical pursuit carried out by generations of 'locals' as well as landowners. Secondly, they have personally connected contemporary deer-stalking practices with the protection of 'our' (whoever our is) most beautiful animal.

Yet their latest struggle for authority is itself contextualised by this centuries-old form of land management. This is to say, that landowners' contemporary claim to authority is not simply based on their ability to manipulate the land the way they want (through controversial developments, etc.), rather it is a manipulation which is compatible with established management techniques. Here, their authority is not just based on their 'status' as McCrone et al. argue, but on the way their practices relate to other agents' practices in the Scottish field.

In this sense, landowners are the products of particular histories that endure in the practices of their land management regimes, which see red deer as quarry, for example. This is their habitus. In this sense, their practices can never be analysed adequately as the outcome of conscious endeavour; one in which they can be seen to purposefully take on the trappings of a particular lifestyle. Rather, landowners' practices are the product of an encounter between a habitus and a field which are, to varying degrees, compatible or congruent with one another.

NOTES

1. The land problem is one which has taken on greater impetus with the creation of new governmental legislation aimed at changing the way land is owned and managed in Scotland. This legislation is some of the first the Scottish Parliament has considered and makes up some one-third of the present Executive's legislative agenda.

2. By charging a 'minute of waiver' the 'feudal superior' can choose to charge a business or house-owner who is obliged to inform this superior of any building developments they may want to carry out, for this work.

3. McCrone (1997) and Williams (1973) argue that for most Scottish people, 'landownership issues' are associated with Highland estates, and 'land' is seen as a rural problem. But, McCrone continues, this is not to say that the Scots care little about the 'land' question: On the contrary, 'land' is a phenomenon directly related to political change, where the ambiguous term 'country' binds notions about the land to politics and is thus linked itself to ideas of 'nationhood'.

4. Sociologically, symbols are taken as 'conventionally' connecting meaning and sign, rather than their being connected 'naturally' through some scientific law (Jary and Jary 1991). But 
this dichotomy between convention and nature is problematic - the objective meaning, which flows from so-called 'natural' signs, is no longer as clear cut as it once was. For the past fifty years 'natural meaning' has come under the analytical gaze of various prominent social thinkers (see, for example, Kuhn 1970). These theoreticians have challenged the impartiality of 'natural science' by documenting the importance of its social production. In so doing, a number of particular methods of analysing science have been developed, including the Sociology of Scientific Knowledge (SSK). In this study, I intend to build on the SSK approach using Bourdieu's theoretical framework (Bourdieu 1977) to show how certain 'natural' symbols can be seen to connect meaning with convention, or in this case land with tradition.

5. Because of the shortage of literature on the subject of Scottish landowners, I have concentrated on two texts primarily - those by Cannadine and McCrone et al. I would like to note my greater familiarity with the work of the latter, however, given that I was a student under McCrone for my first degree at Edinburgh University. He was also my supervisor on a dissertation which formed the basis of my doctoral thesis. To this extent his work is used extensively, albeit critically.

6. McCrone et al. viewed the 'natural' heritage as beyond the scope of their study which dealt with the 'built heritage' (1995:76). However, I argue that the natural heritage can also been seen as part of the built heritage - that they are intimately linked. This is to say that nature in Scotland is as human as the built environment. In other words, nature is constructed (see chaps 7 and 8).

7. This argument is more fully made in my doctoral dissertation, 'Science as Practice: Conserving Scotland's Natural Heritage', and here I have presented a condensed version.

8. Bourdieu defines a symbolic resource as any one or combination of three forms of general capital in circulation; economic, cultural and social. Economic capital refers to money matters; cultural capital refers to cultural goods like educational qualifications, learned publications, etc.; and social capital refers to the advantages of personal associations. By pointing out the regularities among the types of capital and their frequency of use, the underlying internal symbolic structure of the field could be revealed (see Bourdieu 1991).

9. For Weber (1978), there are other forms of group formation and collective action independent of class. He argues that there are another two bases for these activities. In particular, groups form because their members share similar 'status situations'. Whereas class refers to the unequal distribution of economic rewards, status refers to the unequal distribution of 'social honour'. Occupations, ethnic and religious groups and most importantly styles of life are accorded differing degrees of prestige or esteem by members of society. A status group is made up of individuals who are awarded a similar amount of social honour and therefore share the same status. A third type of group formation is defined by Weber. He argues 'parties' are groups specifically concerned with 'the acquisition of social power'. In all, depending on which form(s) of power were significant and on how each related to the other(s), the expectation is that societies will differ in their power structure. For example, economic power may predominate in capitalist societies, but how it integrates with other forms will reflect the historical context of each. Power structures will be differently configured in Britain and the United States (as indeed I argue they are between Scotland and the rest of Britain), even though both are ostensible 'capitalist' societies.

10. McCrone et al. use status to account for the ascendancy of lairds in Scottish society. However, the concept of status as used by these authors has been, I argue, operationalised as a characteristic of an individual. For example, they argue how an individual's 'style' of 
life is an essential component in their 'status' position, while this style - matters of dress, decorum, diet and ritual - can be seen as an important part of their status. Here, the underlying notion of how this status was constructed (for example, Turner 1994) gets lost in its practical operationalisation.

11. Although Turner is quite critical of Bourdieu's articulation of 'practice', which I otherwise use here to help resolve the problem of reproduction, his clarification of this problem is useful for helping elucidate its nature and character.

12. Weber, in attempting to account for the reproduction of implicit lifestyles, has coined the term 'imitation'. However, only external conduct can be imitated. An internalised trait, such as an idea or a disposition, cannot be imitated, at least not directly. For example, one scientific journal can be read by many scientists, but the moment the words of the text leave the page, its similarity ceases to exist. Scientific texts, similar to utterances, are subject to interpretation (see Collins 1985).

13. Turner, in his book The Social Theory of Practices: Tradition, Tacit Knowledge, and Presuppositions (1994), has extracted at least two ways in which sociology has dealt with the problem of reproduction. Firstly he describes as the best-established of these (p. 63), that which accords more privilege to speech than writing, that is, that face-to-face interaction and dialogue is a uniquely powerful basis for reproduction. A second approach he defines is that which tries 'to identify a special stage in development in which "imitation" occurs as a process which is automatic, unreflective, and therefore duplicative' (p. 64).

14. Those 'durably installed generative principles' which produce and reproduce the 'practices' of a social grouping (Bourdieu 1977, 1984)

15. Deer traps have been archeologically investigated, but little is known of their role in the community and questions still remain unanswered as to their social significance. For example, could they have been purely functional, helping the community to feed itself, or, as I suspect, do they have symbolic significance, filling a religious or some other important cultural role.

16. By the Middle Ages I mean $c .1000$ to 1500 .

\section{REFERENCES}

Barnes, B. 1981. 'On the 'Hows' and 'Whys' of Cultural Change' (response to Woolgar). Social Studies of Science 11:481-98.

Bourdieu, P. 1977. Outline of a Theory of Practice. Oxford: Oxford University Press.

Bourdieu, P.1984. Distinction: A Social Critique of the Judgement of Taste. translated by R. Nice (London: Routledge and Kegan Paul).

Bourdieu, P. 1988. Homo Academicus. Cambridge: Polity Press.

Bourdieu, P. 1991. Language and Symbolic Power. Cambridge: Polity Press.

Cairns, C. 1996.'The laird rules ... OK?.' The Scotsman, 21 February.

Callander, R. F. 1987. A Pattern of Landownership in Scotland: With Particular Reference to Aberdeenshire. Aberdeen: Haughend Publications.

Callander, R. 1998. How Scotland Is Owned. Edinburgh: Canongate.

Callander, R. F. and Mackenzie, N. A. 1991. The Management of Wild Red Deer in Scotland. Perth: Rural Forum, Scotland.

Cannadine, D. 1990. The Decline and Fall of the British Aristocracy. London: Yale University Press.

Chatteris, Lord of Amisfield 1991. Hansard, House of Lords, 22 January.

Collins, H. M. 1985. Changing Order. London: Sage.

Cramb, A. 1997. Who Owns Scotland. Edinburgh: Mainstream Publishing. 
Darling, F. F. 1937. A Heard of Red Deer. London: Oxford University Press.

Dressler, C. 1998. Eigg: The Story of an Island. Edinburgh: Polygon.

Fergusson, J. 1949. Lowland Lairds. London: Faber and Faber.

Gill, R. 1990. Monitoring the Status of European and N. American Cervids. Nairobi: UNEP.

Grant, J. 1991. Rothiemurchus Estate: Visitor Guide and Footpath Map. Battleby: Scottish Natural Heritage.

Grimond, Lord 1991. Hansard, House of Lords, 22 January.

Hart-Davis, D. 1978. Monarchs of the Glen: A History of Deer Stalking in the Scottish Highlands. London: Cape.

Hunter, J. 1995. On the Other Side of Sorrow: Nature and People in the Scottish Highlands, Edinburgh: Mainstream.

Jary, D. and Jary, J. 1991. Dictionary of Sociology. Glasgow: Harper Collins.

Johnston, T. 1911. Our Scots Nobel Families. Glasgow: Forward.

Knorr-Cetina, K. D. 1979. 'Contextuality and Indexicality of Organisation Action: Toward a Transorganisation Theory of Organisation'. Social Science Information 18:79-101.

Knorr-Cetina, K. D. 1981. The Micro-sociological Challenge of Macro-sociology: Towards a Reconstruction of Social Theory and Methodology', in K. D. Knorr-Cetina and A. V. Cicourel (eds.), Advances in Social Theory and Methodology: Toward an Integration of Micro- and MacroSociologies. Boston, Mass.: Routledge and Kegan Paul.

Kuhn, T. 1970 [1962]. The Structure of Scientific Revolutions. Chicago: Chicago University Press. Love, J. 1980. 'Deer Traps on Rhum', in Deer 5:131-2.

McCrone, D. 1992. Understanding Scotland: The Sociology of a Stateless Nation. London: Routledge. McCrone, D. 1997. Land, Democracy and Culture in Scotland. Perth: Rural Forum Scotland.

McCrone, D., Morris, A. and Kiely, R. 1995. Scotland the Brand: The Making of Scottish Heritage. Edinburgh: Edinburgh University Press.

McEwen, J. 1977. Who Owns Scotland? A Study in Land Ownership. Edinburgh: Edinburgh University Students' Publications Board.

Millman, R. 1971. Maps of Scottish Estate Boundaries in 1970. Edinburgh: Scottish Records Office.

Outterside, N. 1996. 'Eigg ultimatum to landlord'. The Scotsman, 31 January.

Pearson, Lord of Rannoch 1991. Hansard, House of Lords, 22nd January.

Samuel, A. M. M. 1996. 'Science as Practice: Conserving Scotland's Natural Heritage'. University of Lancaster, doctoral dissertation.

Samuel, A. M. M. 1998. 'An Integrated Conservation Policy for Scotland: A Rhetoric which Belies Practice'. Scottish Affairs 23.

Scottish Natural Heritage 1994. Red Deer and the Natural Heritage: SNH Policy Paper. Perth: Scottish Natural Heritage.

Timperley, L. 1980. 'The Pattern of Landholding in Eighteenth-Century Scotland', in M. L. Parry and T. R. Slater (eds.), The Making of Scottish Countryside. London: Croom Helm.

Turner, S. 1994. The Social Theory of Practices: Tradition, Tacit Knowledge, and Presuppositions. Chicago: University of Chicago Press.

Wacquant, L. D. 1989. 'Towards a Reflexive Sociology: A Workshop with Pierre Bourdieu'. Sociological Theory 7:26-63.

Weber, M. 1978. Economy and Society. London: University of California Press.

Wightman, A 1996. Who Owns Scotland? Edinburgh: Canongate.

Williams, R.1973. The Country and the City. London: Chatto and Windus.

Biographical note: Having recently completed his doctoral dissertation entitled 'Science as Practice: Conserving Scotland's Natural Heritage', at the University of Lancaster, ANDY SAMUEL is now 
working as a sociology lecturer at the University of Abertay Dundee. Currently he is carrying out funded research into the ownership and management of land in Scotland, looking at 'radically' situated heritage organisations, and how their practices are mediated by those of traditional land management

Address: Division of Sociology, University of Abertay Dundee, 158 Marketgait, Dundee, Scotland, DD1 $1 \mathrm{NJ}$. 